\title{
CENDANI BAMBOO TRADITIONAL FISHING JORS INDONESIAN MASTER WORKS
}

\author{
By : \\ Endang Naryono \\ LECTURER OF STIE PASIM SUKABUMI
}

\begin{abstract}
ion :
Cendani bamboo or kirisik bamboo with the Latin Phyllostachys aurea, is a type of bamboo that grows in Indonesia which has been used and used by Indonesian people for hundreds of years. This bamboo has a unique character and has a beautiful artistic value, has a height between 2 to 4 meters, with an average diameter of less than $4 \mathrm{~cm}$ so that bamboo is very widely used by the community in supporting daily activities, such as clotheslines, building materials, household crafts and more prominently this bamboo is used for fishing rods. The rod from Cendani bamboo is very fast, this is due to advances in science and technology as well as the progress of the times, on the one hand it is very encouraging because it will increase the economic value of the community in their welfare but on the one hand the massive exploitation of cendani bamboo will affect the ecosystem and development. it is proving increasingly difficult to get old Cendani bamboo to use as fishing rods. Currently, the cendani fishing rod is no longer considered a one-sided rod or a cheap fishing rod that is not the main choice of anglers, but now the cendani bamboo rod is an exclusive fishing rod that is highly sought after by customers from medium to premium prices. So that cendani bamboo has a high economic value that must be maintained and increased its economic value for welfare.

Keywords: Cendani Bamboo, Fishing Rod
\end{abstract}

\section{A. INTRODUCTION}

Bamboo, as a typical plant that grows in the suburbs in Indonesia, has many uses. One of them, as recorded in various writings about the history of the Indonesian nation, bamboo was used as a weapon, namely bamboo spears during the Independence Revolution. But at this time, the plant is often forgotten so that it tends to be a worthless liar plant. Whereas bamboo has benefits ranging from cultural, economic, and environmental benefits. Bamboo should not be forgotten, but paid attention because this plant is a very useful plant in the future. Bamboo was instrumental in liberating the Indonesian people from forced hands, and is now forgotten. Tend to be a liar plant, there is no special bamboo plantation, even though bamboo is the future just like later our 
clothes are made of bamboo fiber, which has been done by Japan, like a plant that is better than cotton.

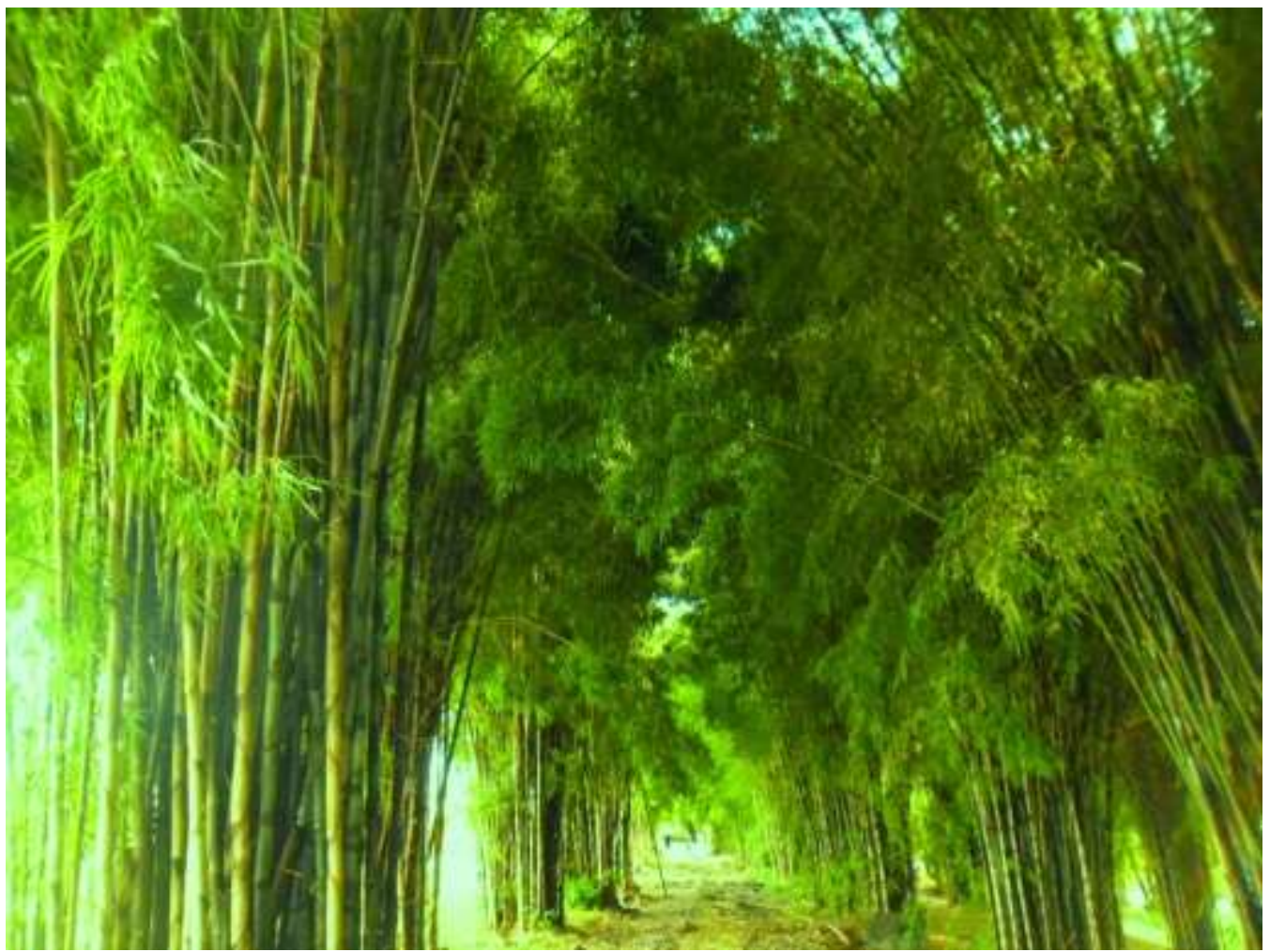

Bamboo Forest in East Java

Source: MTB FM

This plant has thousands of benefits, the bamboo plant should not be forgotten, it must even be worked on seriously for industrial purposes. Currently, the bamboo industry has not yet emerged in Indonesia. This is because bamboo cultivation has not been done seriously. There can be no bamboo industry in Indonesia if plantations are not cultivated seriously. Until now there are still many basic problems to raise bamboo plants. We do not know how many thousand hectares of bamboo plants in Indonesia. We don't know how to plant it. We don't know what the industry is like. We don't know what we have. In fact, from one thousand and fifty-eight ethnic groups and thousands of islands that we have in Indonesia, all of them process bamboo in different ways. 


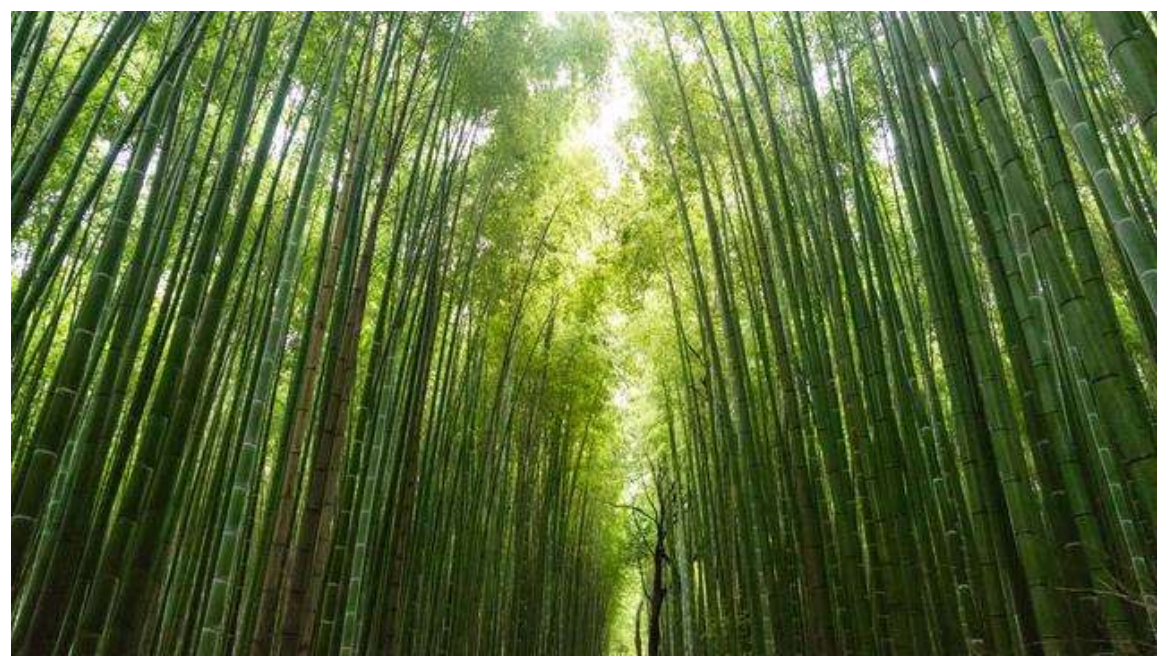

Bamboo Forest Tour in East Java

Source: Liputan6.com

Traditional houses throughout the archipelago have a bamboo component. Efforts to campaign for the preservation of bamboo plants, can be started very simply. For example, teaching how to plant bamboo, choosing the time of cutting, to how to cut down. In particular, the cutting time must be very appropriate, i.e. do not cut the bamboo while the shoots are growing. there should be a government regulation regarding this, it is forbidden to cut bamboo when the bamboo shoots out, because this will cause the mother bamboo to die. There are three benefits of bamboo, namely cultural, economic, and environmental benefits. Bamboo has been proven to have cultural benefits where since ancient times bamboo has been used for various products ranging from furniture, weapons, to artistic tools that we can still find today.

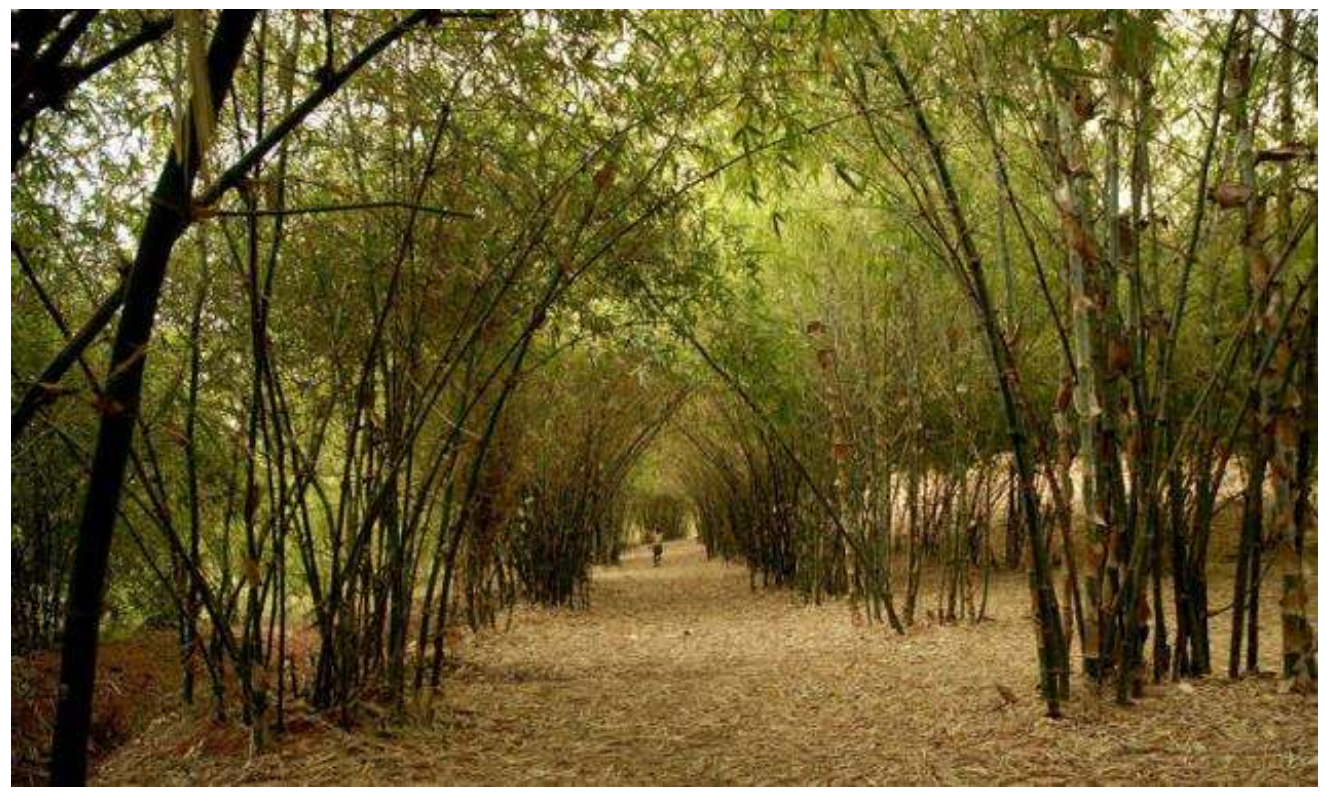

Types of Bamboo in Indonesia 


\section{Source: Flanter and Forester}

The economic benefits of bamboo are also great. Planting bamboo for one clump will produce three hundred bamboo sticks. If planted on one hectare of land with a thousand clumps, two hundred thousand bamboo sticks will appear which can be used for various purposes and can overcome poverty, which has been high in poverty in Indonesia. One of the reasons is that the unemployment rate is still high, with bamboo cultivation will create jobs that will reduce unemployment which will eventually reduce poverty. There are also obvious environmental benefits. One bamboo stick can produce one point two kilograms of oxygen. Its roots can absorb ninety percent of rainwater. This will reduce drought and the risk of landslides and floods in the country.

\section{B. CENDANI BAMBOO}

Bamboo is a type of plant that belongs to the class of grasses with special characteristics of hollow stems and segmented segments. There are many types of bamboo, each of which has a different morphology. Bamboo develops with shoots emerging from the roots. Bamboo growth is quite fast, it can even reach $60 \mathrm{~cm}$ in a day (Farrely, 1984).

Many mention that bamboo is a tree that provides so many benefits and uses or is versatile for the needs of human life. Even in this modern and sophisticated era, bamboo is still widely used for various purposes from the simplest to designed in various artistic modifications of high value. From small toothpicks to building houses made of bamboo. This shows that there are so many benefits and uses of bamboo for humans. As a tree with a trunk that grows upright and towering, it can reach a height of more than 10 meters, it turns out that there are bamboo that grow stems or branches from its eyes with a shape that has its own unique shape. To find or get a unique shape of bamboo is not easy, it can be difficult, aka rare. Because it is not necessarily among the 1000 bamboo sticks found there is a unique shaped bamboo. Don't be surprised if this unique type of bamboo is quite rare. If you happen to be able to find or get the bamboo, it's called meeting a mate, aka bamboo petuk (meet). 


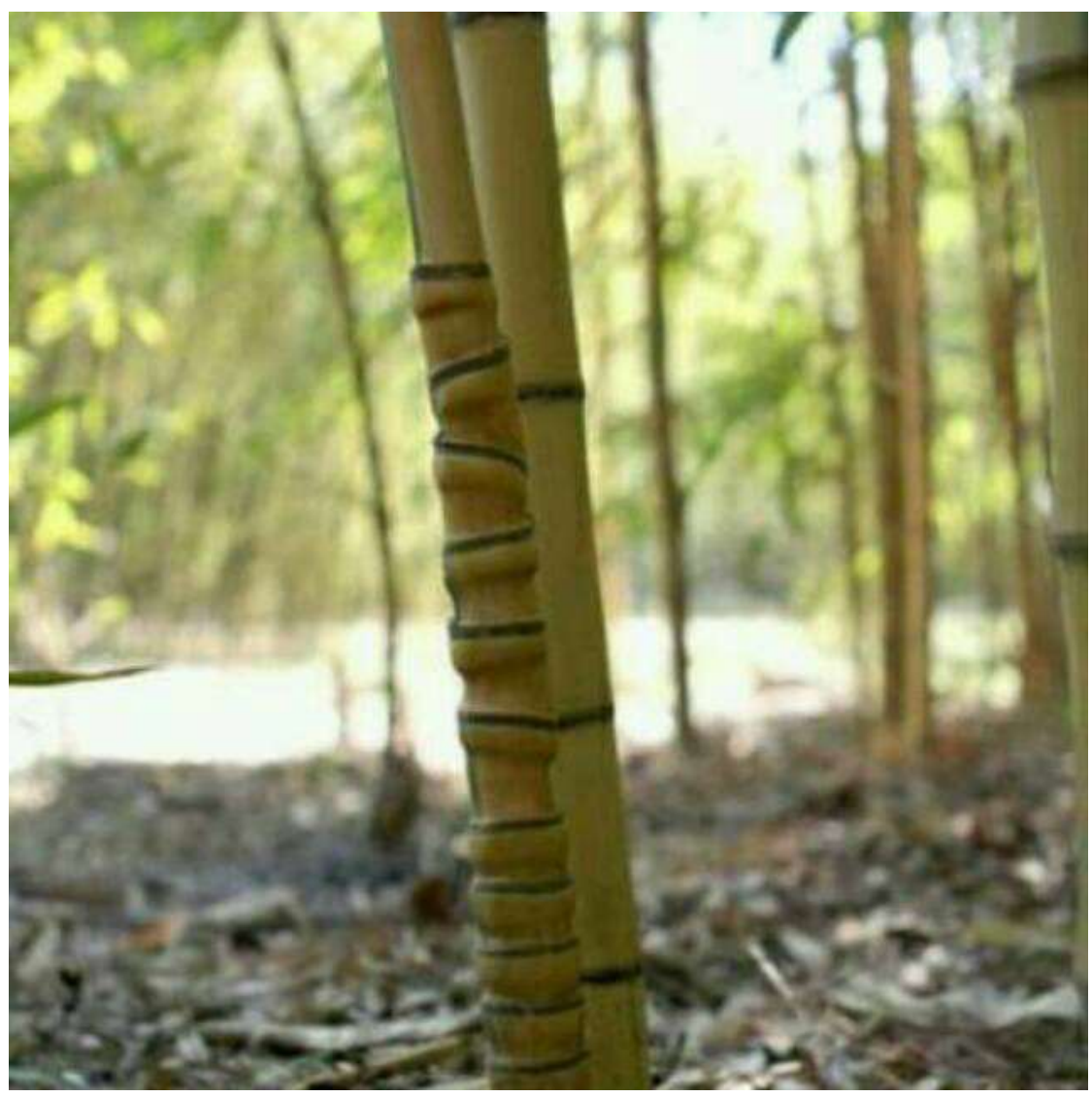

Sandalwood Bamboo

Source: Dieng Tourism

Cendani bamboo (Phyllostachys aurea) lives in cold mountainous areas. This type of bamboo has the characteristics of short segments that make it look unique and futuristic. This feature is used for making fishing rods. The short segments make fishing rods from cendani bamboo stronger when they bend due to the pull of the fish. In addition, its unique shape makes it liked by many people. Even the price of fishing rods from cendani bamboo reaches millions of rupiah. There are so many types of bamboo that make it very prospective to be developed en masse in Indonesia. Bamboo can be a non-timber forest product that will increase state income apart from wood products. In addition, for the community, bamboo can be used as a valuable processed product. From an environmental point of view, bamboo becomes a water-absorbing bag through its roots (Soekartawi, 1995). 


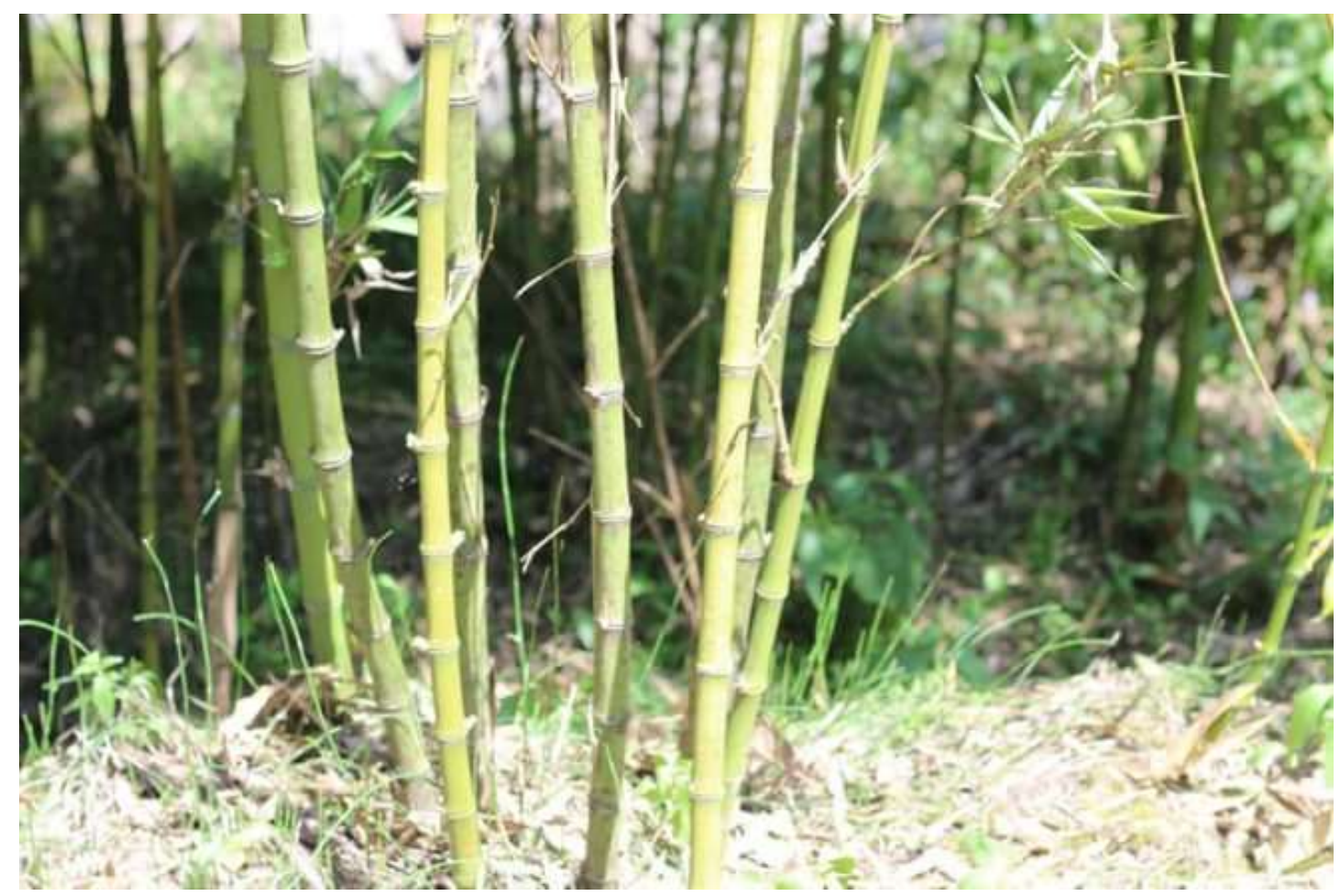

Sandalwood Bamboo

Source: Dieng Tourism

In addition to storing artistic uniqueness, are there any specifications of the benefits and uses of unique, natural and step-by-step bamboos, not man-made, Many people believe that this rare unique bamboo with certain specifications has natural innate power energy, or natural energy. No wonder then there are people who say that this unique and rare type of bamboo is believed to be 'lucky'. Of course, all of that is returned to the beliefs or suggestions of each person who believes it or not. But at least all of that or this belief we return to the greatness of Allah S.W.T

The type of bamboo according to the specifications of the unique artistic shape is believed to have certain uses as well. For example, to reject negative energy, such as teluh, witchcraft or magical fences. And some are intended for smooth business or authority, and so on. No wonder we hear people looking for certain types of bamboo for their needs on the basis of their beliefs. But it all comes back to the beliefs of each individual. 


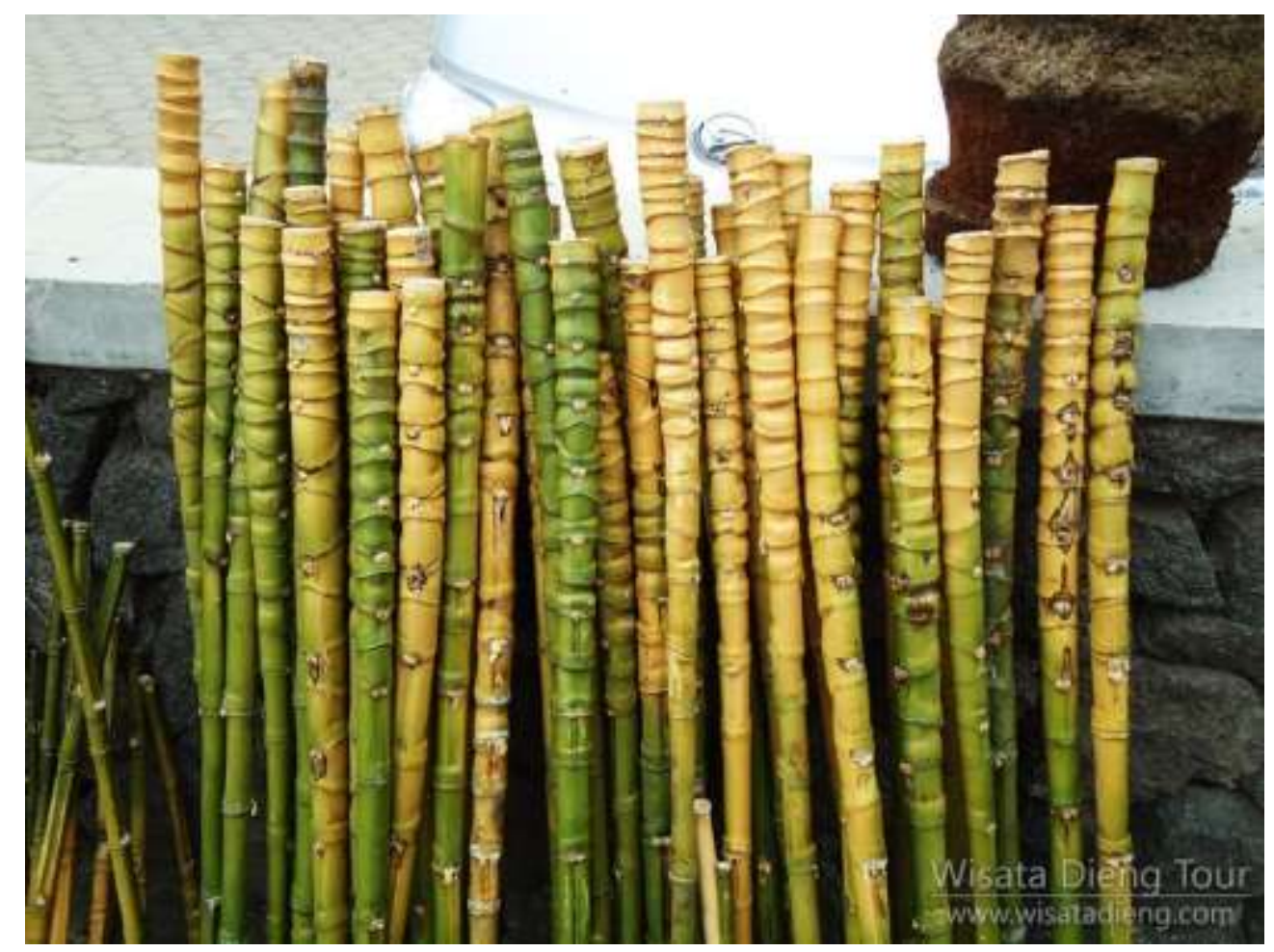

Cendani Bamboo Rod Handle

Source: Dieng Tourism

The price of this bamboo varies from tens of thousands, hundreds of thousands to millions of rupiah. Depending on the specifications of the uniqueness and rarity of the bamboo, even to the suggestion of whether this bamboo is lucky or not. Here people believe that the bamboo has the power of energy.

For example, What is meant by the presence of natural energy power that surrounds the bamboo. For example, there is a clump of bamboo that has been cut as high as $60 \mathrm{~cm}$ and has been charred, it turns out that in the middle there is a bamboo with an odd shape (unique) that doesn't burn, it's still smooth. Doesn't burn at all. While others were charred, some were even destroyed in the fire, is this what people call fireresistant bamboo. 


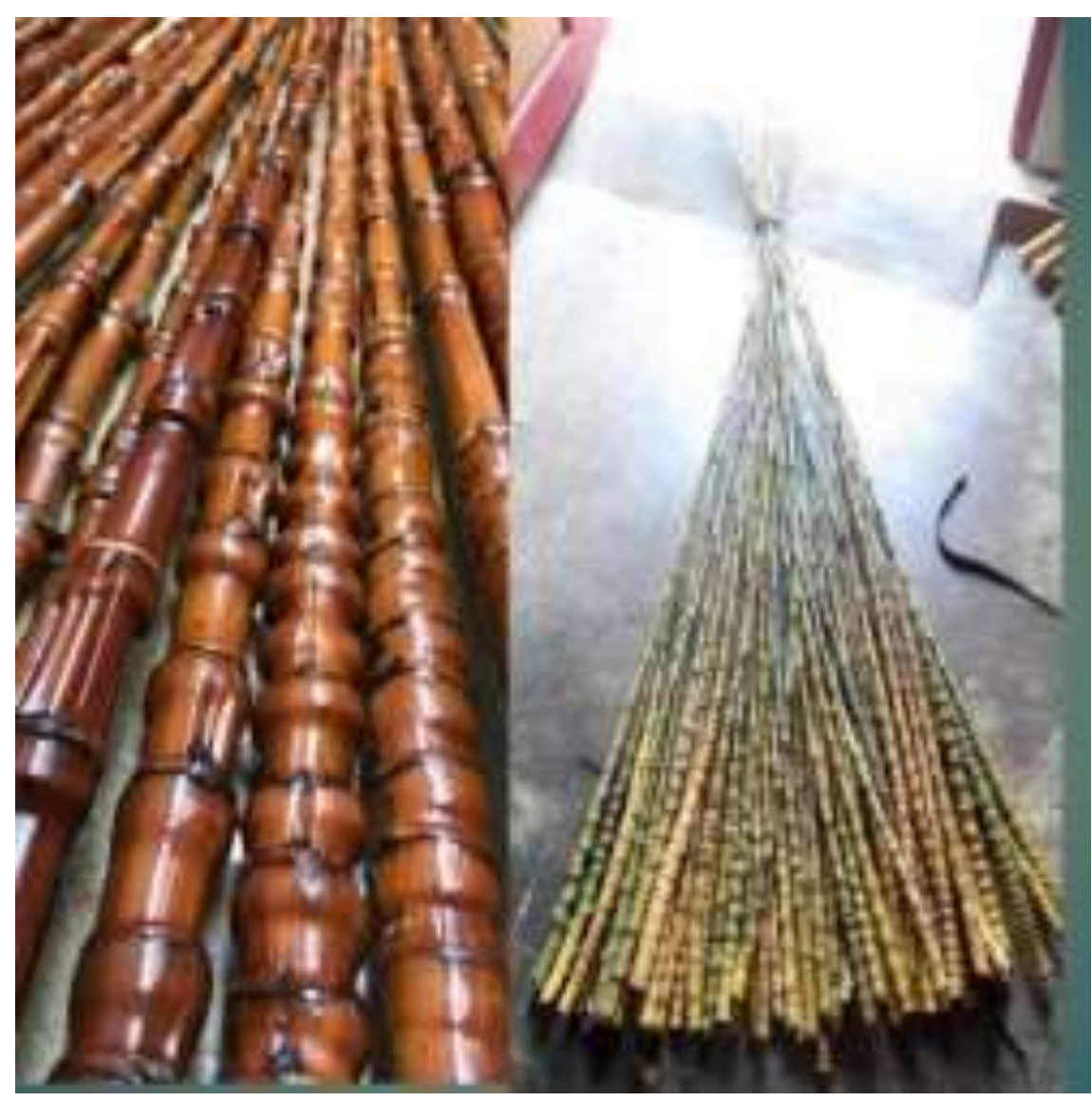

Bamboo Cendani Lane

\section{Source: Dieng Tourism}

The cendani bamboo rod has unique characteristics in each region, different regions, the shape of the rod is different even though they both use sandalwood bamboo. In Central Java and East Java as the center of quality sandalwood bamboo. this is because the sandalwood bamboo center is relatively hot with mountainous geography so as to produce high quality cendani bamboo motifs and qualities such as wonosobo and dieng districts. the majority use cendani bamboo only for the rod handle or joint section, while for the top section they use fiberglass, solid carbon or mix carbon. While in West Java this rod is the prima donna of anglers, even to the point that some buy it at a price of millions of rupiah to buy one rod of rod material, the difference is that in West Java, using sandalwood rods from top to bottom, completely using sandalwood.

Along with advances in technology and information as well as the development of cendani fishing rods, starting from the processing of raw materials to product differentiation, now bamboo cendani fishing rods are not only in variations of classical fishing rods but have many product variations from classic, semi-modern and even modern fishing rods, so that in the long term The cendani bamboo rod can be developed again so that it has a high economic value which will certainly benefit the community and the national economy. 


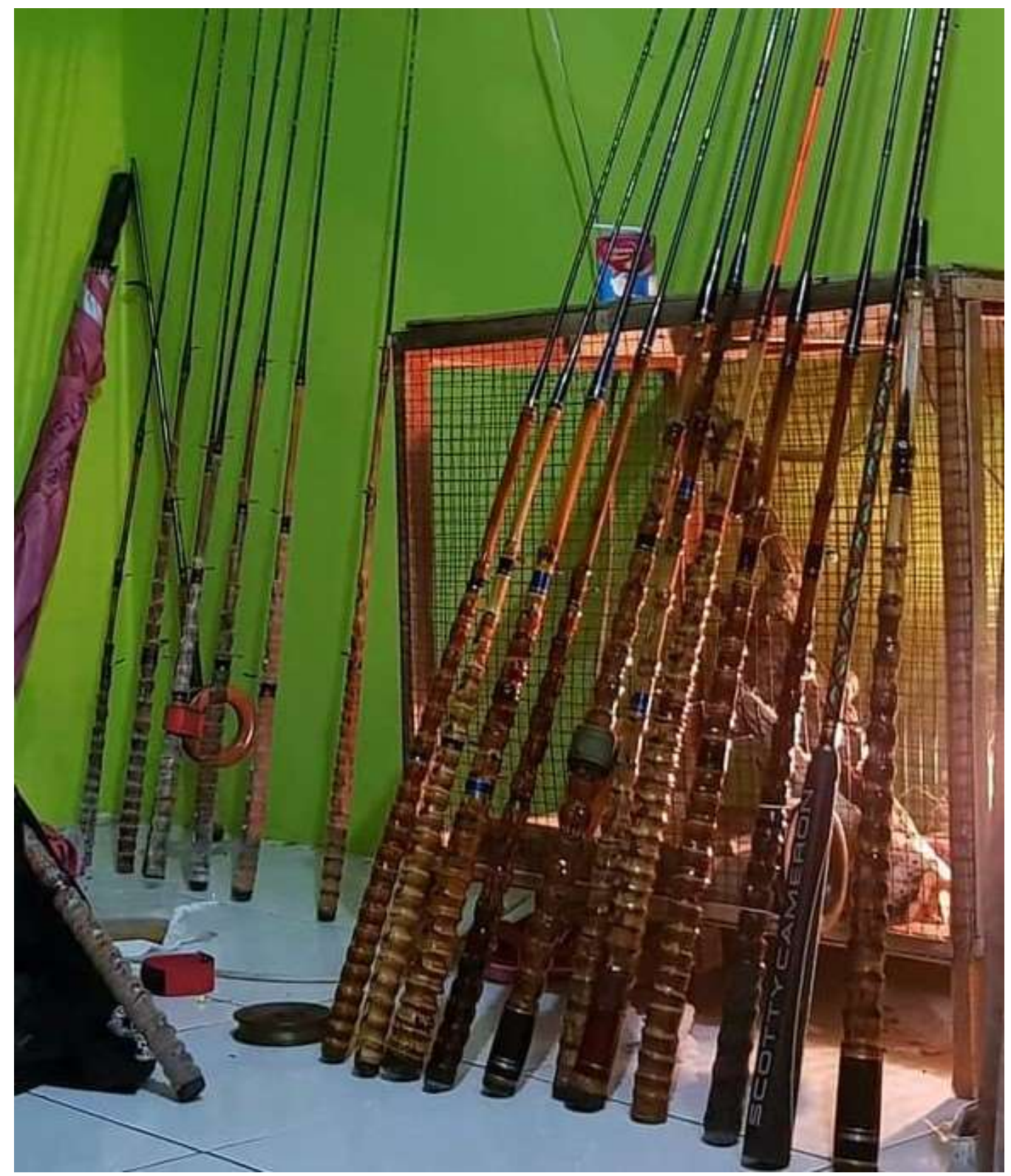

Raft Cendani Bamboo Rod

Source: caturwid.org

\section{CENDANI BAMBOO PROCESSING}

The processing of sandalwood bamboo is currently very developed compared to previous years, it is directly proportional to the increase in economic growth which has an impact on the increase in people's economic income which fosters interest in people who have a hobby of fishing and have multiplayer in the increase in fishing business and fishing tourism Positive things must be developed seriously and professionally.

The processing of sandalwood bamboo in Indonesia in general still uses the traditional method of processing this sandalwood, especially for fishing rods. The method of processing or processing cendani bamboo which I will discuss here is the 
bamboo used for the handle of the rod and fishing rod. Because the bamboo cendani process for craft materials is generally only dried naturally or by means of an oven. Be it a traditional (charcoal) oven or an oven chamber.

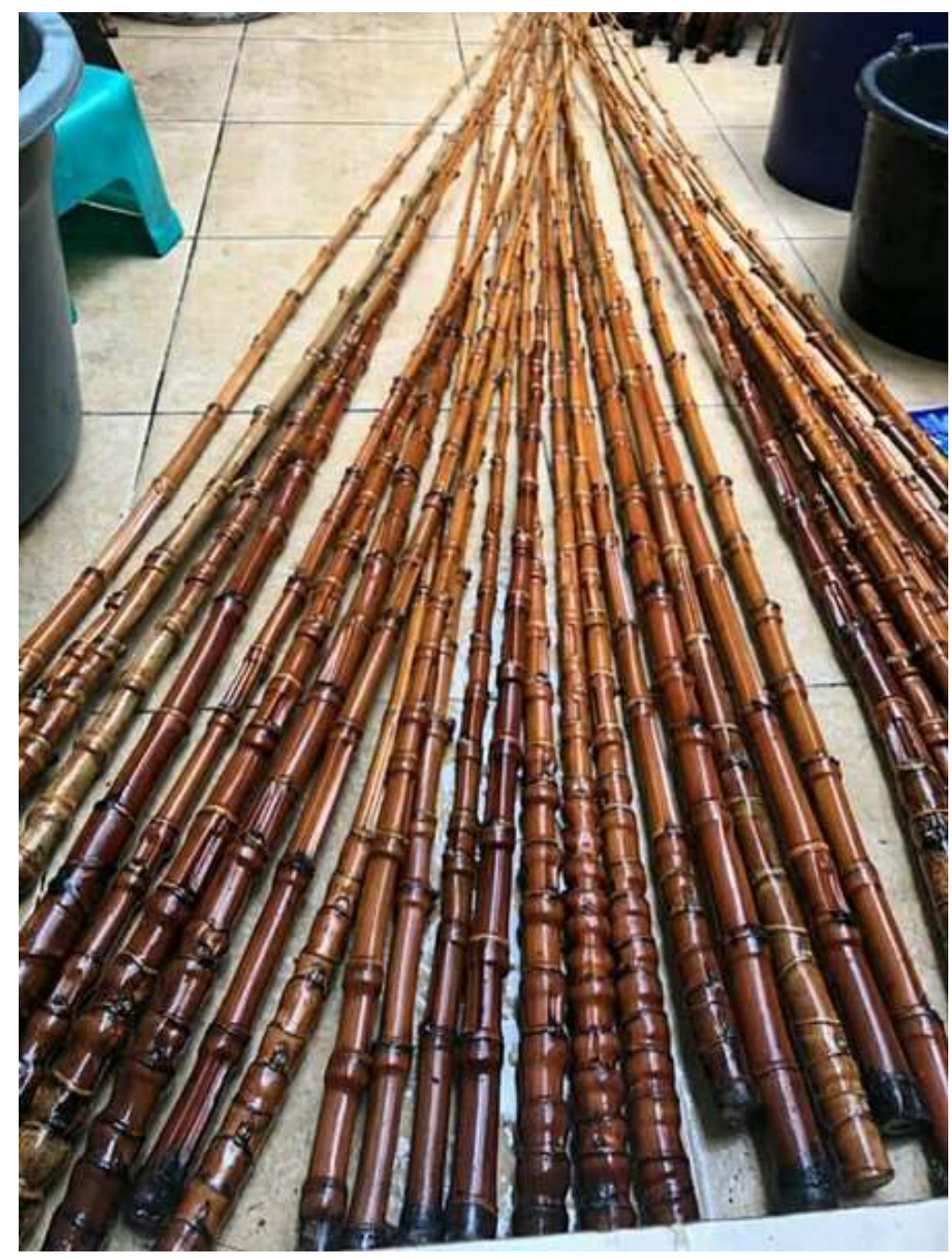

Bambu Cendani Lajur yang telah direndam dengan minyak

Sumber : duniamancing.com

\section{Soaking with Used Cooking Oil}

Bamboo Cendani for fishing rods before being formed into rods goes through a long process and requires patience in processing it. Processing using cooking oil is usually used cooking oil or used cooking oil that is no longer used, or the quality is already bad. To get it is easy but difficult if for the family environment it is definitely difficult to get it, even if there is a certain amount of volume. Usually to get it through street vendors, fried food businesses, restaurants, factories or now we can get it from online shops that sell used cooking oil. Prices vary from Rp. 3000 to Rp. 5000/ liter depending on the quality of the oil.

The processing method is very easy and simple, we need a container that fits our needs, the more Cendani bamboo that is soaked, the bigger the container used and the more used cooking oil is needed. Like a used drum, a kind of big bucket, except for the 
type of immersion bamboo cendani lanes need a container that is between $150 \mathrm{~cm}-200$ $\mathrm{cm}$ long like a paralon whose diameter adjusts to needs. Bamboo cendani soaked for 3-4 months using cooking oil after soaking and then drained for approximately one week or 7 days. Then soak again as needed, usually the desired color, the longer the sandalwood is soaked, the darker brown it will approach black. The climate of the region is very decisive in immersion, areas with cold climates will have an impact on the oil which will thicken more so that it will interfere with the soaking process and require more oil than hot climates.

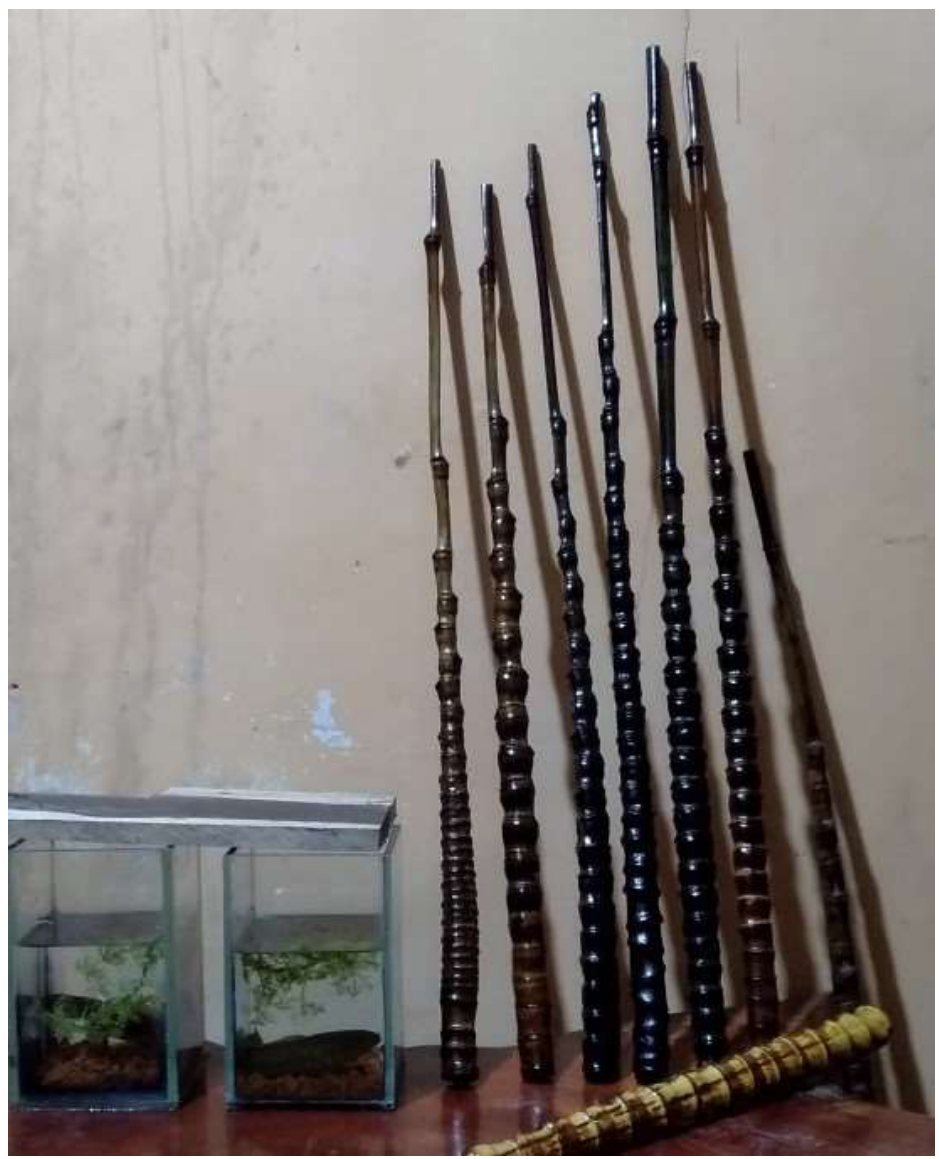

Oil-soaked Cendani Bamboo Rod Handle

Source: caturwid.org

The advantage in processing sandalwood bamboo by soaking it in oil is that the bamboo becomes more durable, not dry and easy to break. This is due to the function of the oil in the bath as a substitute for water when the bamboo is not yet processed. The oil will enter through the bamboo pores and will settle on the bamboo segments so that the bamboo will look shiny even though it is not painted, this is because the oil has seeped into the bamboo fiber as a whole. Bamboo soaked in oil will have a heavy weight this is due to the absorption of oil into the bamboo, so usually before the assembly process the bamboo is dried in the sun with the humidity level according to the needs or desired. 


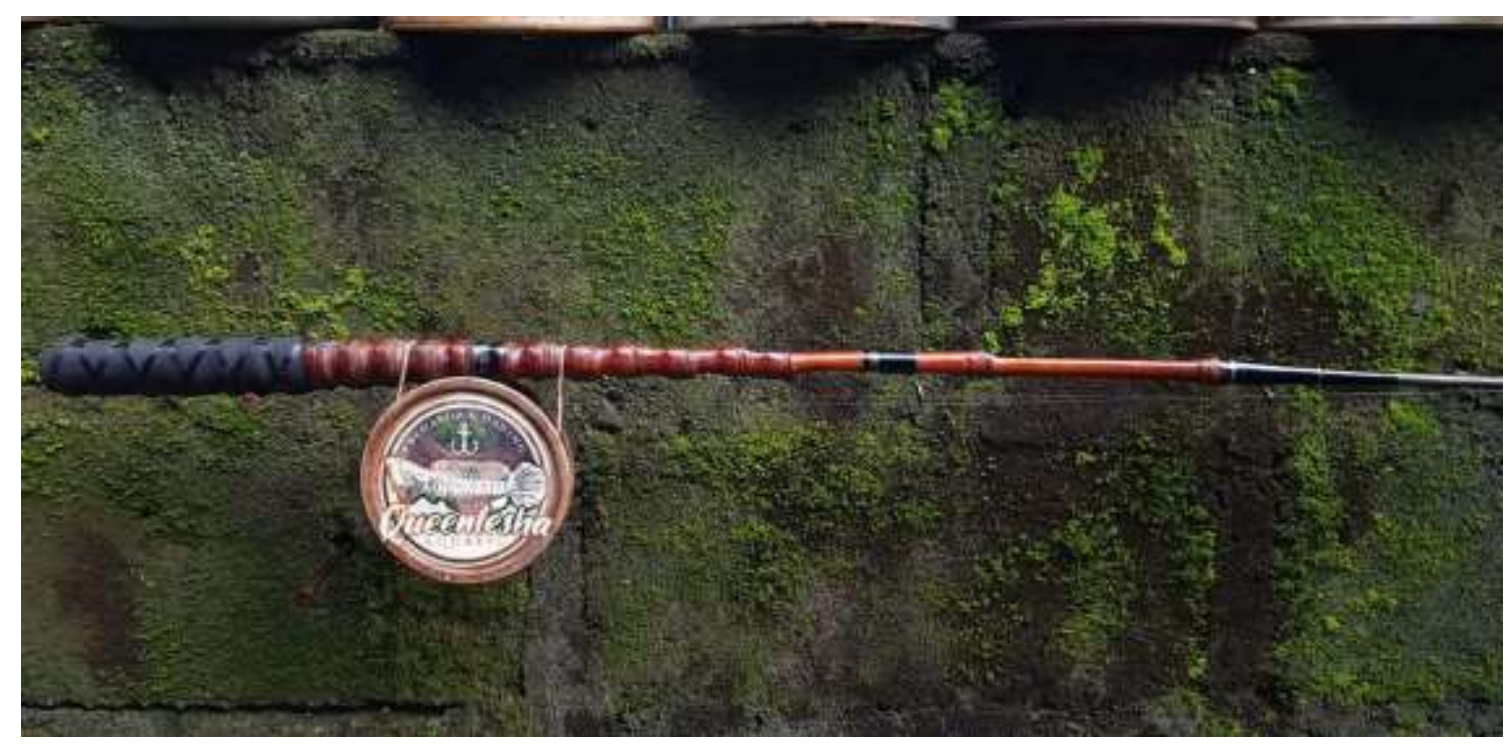

Cendani Bamboo Rod

Source: caturwid.org

The longer the bamboo is soaked, the darker the color, usually to get the black color it takes a long time between 2-3 years depending on the quality of the bamboo, the older the soaked bamboo, the darker the color, this is due to the density of the fiber in it The disadvantage in processing using this oil is that it is easy for mushrooms to grow so they need extra care in their maintenance, then they are often eaten by termites and rats so that they need a special place and caution in storing them and the last is that in assembling the fishing rods, extra special glue is needed in the process of wrafting or installing a ring guide because of the large amount of oil stored in the bamboo so that the glue is difficult to stick even if it sticks it will not be as strong as a fishing rod that is not soaked in oil.

\section{Cendani Bamboo Process With Fumigation}

The processing of bamboo cendani with smoking is not new, our ancestors used it hundreds of years ago, it's just that with the rapid progress of science, how to smoke with smoking is starting to be abandoned, although there are still many who use it, especially for business people or fishing rod craftsmen because of the smoking technique. it will get quick results because of the target production capacity. namely the color obtained and the water content in the bamboo will be obtained faster than soaking using oil. 


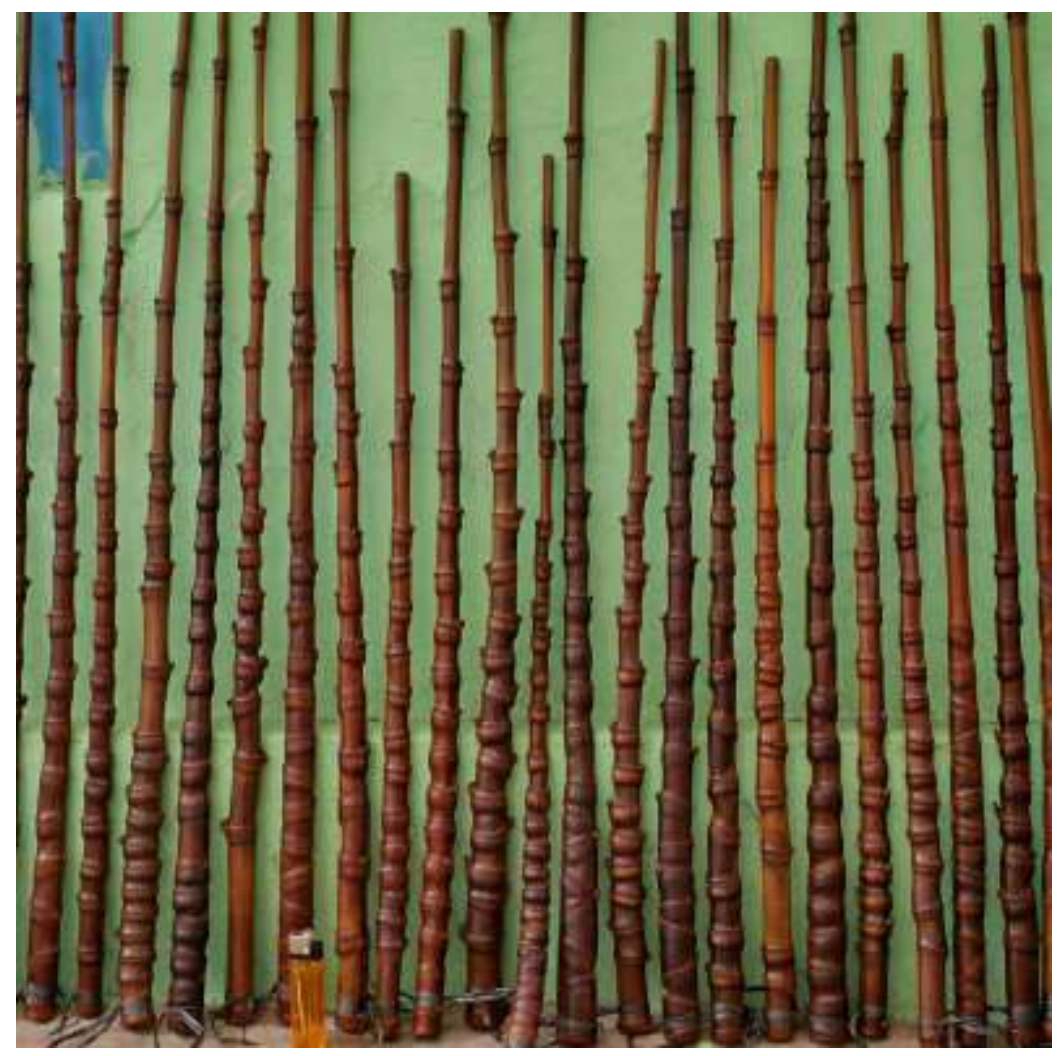

Bamboo Cendani fishing rod handle through the smoking process

\section{Source: Duniamancing.com}

The advantage of this smoking is that it takes a relatively short time of 7-14 days to get the desired results, this smoking process is very suitable for fishing rods of the type sandalwood strip or full sandalwood this is because the low water content in the bamboo makes the bamboo stiff so it has a good tapper and has an action that can be adjusted as needed, the process of straightening the rod is relatively easy and approaches $95 \%$ precision or straight, the rod becomes stiff so that when we pull the fish after that the rod will be in a straight position as before, the bada is soaked in oil the longer the rod used will be more curved this is the effect of water / oil content in the fishing rod.

The weakness in this smoking process is that the bamboo fiber becomes dry and breaks easily because the water content in the bamboo is small, so the fishing rod with the smoking process requires extra care, namely the rod should not be allowed to dry, for anglers in West Java, before fishing, the rod should be soaked in the fishing pond for 10-15 minutes. before fishing with the aim that the rod is not stiff and easily broken. The fishing rod treatment with this process is actually relatively easy, it just needs consistency, namely by always smearing it with oil when the rod is not used with the aim that the rod's moisture can be maintained so that the rod does not dry and break. 


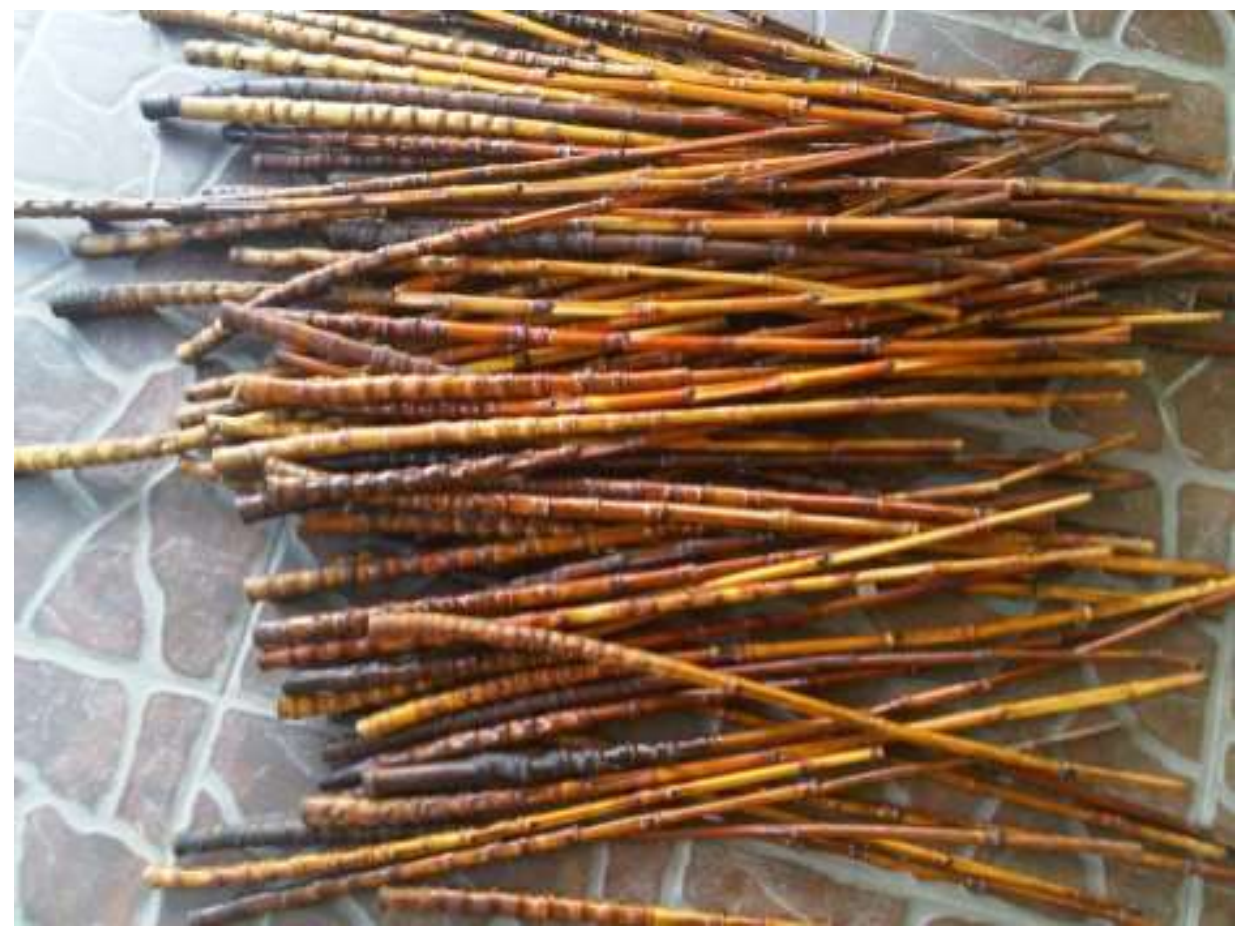

Bamboo Cendani fishing rod handle through the smoking process

Source: Duniamancing.com

The bamboo is smeared with oil (some use used oil), then the bamboo is stored over a fire (usually in the village it is placed on a streamlined pawon) with an ideal distance of 2 meters. Always apply oil at least once every 3 days, while the bamboo is behind so it doesn't brown on the other side, do it for the time / desired results about 3 weeks If Pawon is used every day, usually 1 month has been finished. Smoking on bamboo will be faster, because it is smoked in an enclosed space. Make a stove, then cover it around it using an old banner or zinc. Make a small hole for the air to escape. Before smoking, the bamboo is smeared with oil first. Use husk or sawdust, you can also use coconut fiber, the important thing is that the smoke comes out, not fire. This process is faster, usually 2 weeks so.

\section{Process of Cendani Bamboo by Soaking in Tea and Coffee Water}

Processing with this method is not new, it has been used for a long time, it's just that it is mostly used for wood, especially hardwoods such as teak and camphor, so that the wood has a dark and beautiful pattern. This method can actually be used on cendani bamboo, but only a few people use it, especially fishing rods that rarely use this method. Actually there are two methods, the first is by soaking it in coffee or tea water, the second is just smearing it with tea or coffee water. It's just that the method by smearing it every day will take a very long time to get the color we want.

The advantages of this method are that it is very easy and simple and the most important thing is that it does not produce waste or air pollution such as the method of 
soaking with oil and smoking. The time required is relatively short between 2-3 weeks and the color we get is relatively soft and beautiful with this method, the rod has a soft flexibility or action, this is influenced by the water content in the rod. The drawback with this method is that the bamboo fiber becomes brittle due to the soaking process with water so that it will reduce the quality of the rod fiber, especially the rods that will be used for galatama, of course, it is not recommended to use this method. but for daily fishing speck rods it is still recommended.

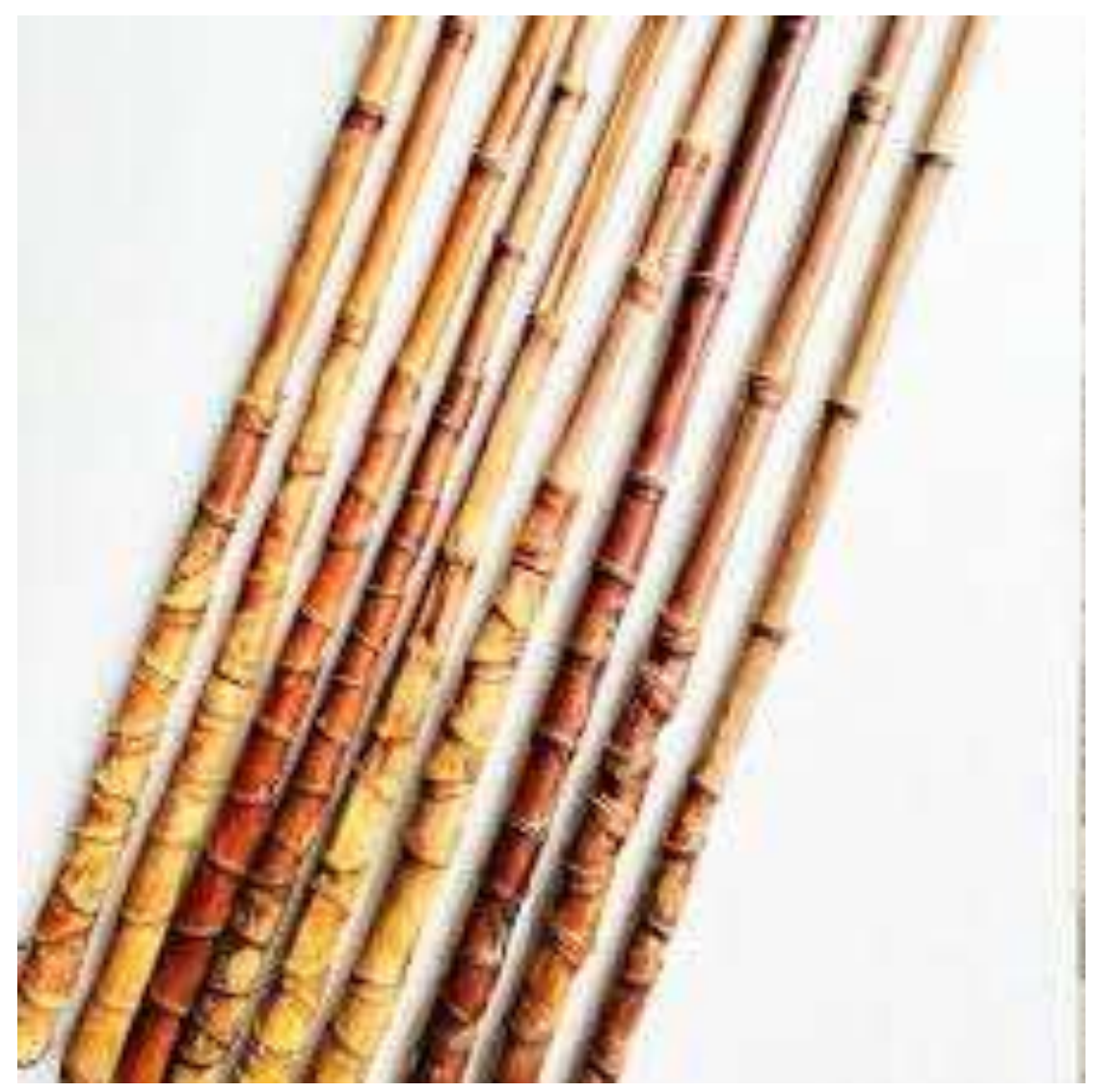

Bamboo Cendani fishing rod handle through the process of soaking with tea or coffee

Source: Duniamancing.com

Bamboo that is stored in a drum or paralon container is stored according to the dimensions of the bamboo, whether it's a rod handle or full sandalwood, then boil water to boil tea or coffee according to the volume needed, usually for one liter of water, 1 small packet of tea is needed, just multiply the need (it is recommended not to use tea bags or teabags) preferably using traditional packaged teas whose leaves and stems are still visible, the excess color is very thick. For coffee, try not to use packaged coffee because usually there are elements other than coffee in it, it's better if we buy coffee beans that are ready for consumption and then ground and boiled. $1 \mathrm{~kg}$ of coffee can be used for 10 liters of water. After boiling, cool the stew after it cools down, then soak the sandalwood bambo. Soak for about 2 weeks after that drain if the color is not what we 
want, the soaking process can be carried out again using the old media if the color is not what we want.

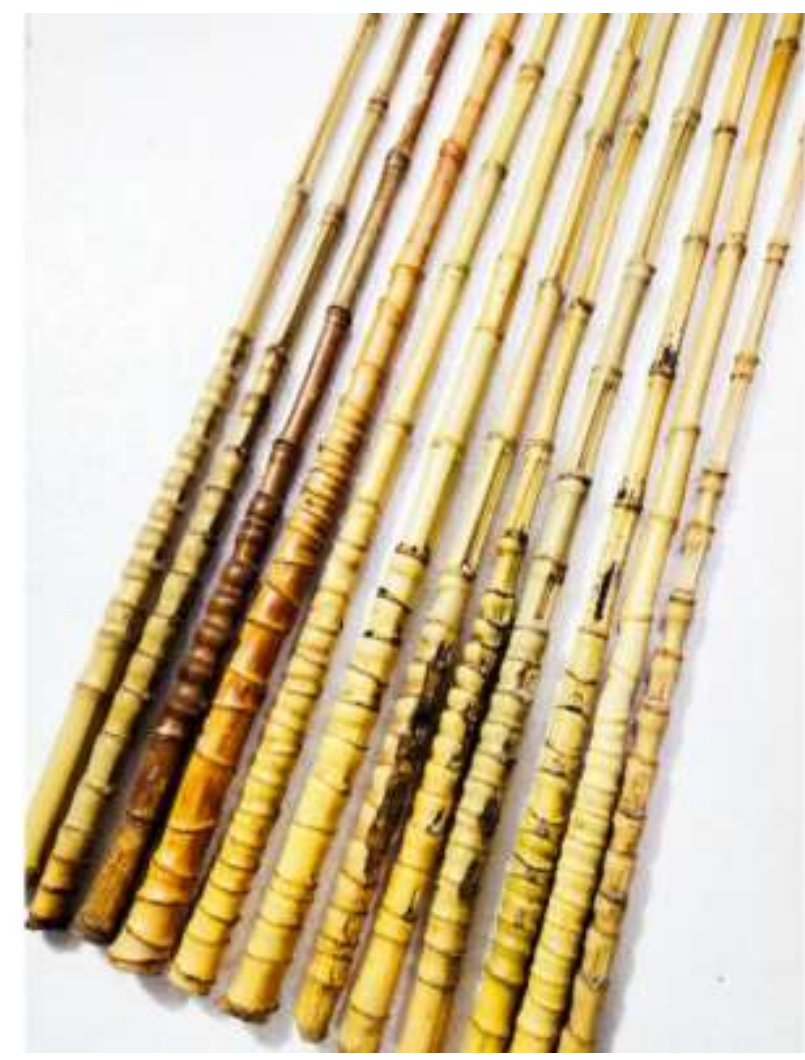

Bamboo Cendani fishing rod handle through the process of soaking with tea or coffee

Source: Duniamancing.com

You can also do a combination by mixing tea and coffee in one bath. The results of those who have done it, the results are not much different from those using only tea or coffee, it just has a unique and distinctive color, some even try it by adding a coil of wire and vinegar in the hope get nicer colors and faster. It's just that until now the author has not obtained the results of the soaking process using vinegar and wire coils.

\section{CLOSING}

Cendani bamboo has a very high economic value and if it is developed professionally by opening a special plantation of sandalwood bamboo by following the industry regarding sandalwood bamboo, it will certainly lead to people's economic growth, namely increasing purchasing power. The use of sandalwood bamboo is still on a micro scale and traditionally produced.

The sustainability of bamboo cendani is increasingly threatened due to continuous exploitation without and continuous replanting so that if this is allowed bamboo cendani 
will be destroyed. The long-term impact of the stake is reduced water absorption, floods and landslides and increased global warming.

The government must have an active role in saving this bamboo by making regulations that protect the existence of this bamboo, such as replanting, harvesting bamboo and protecting bamboo sandalwood forests from land conversion into agriculture, plantations and industrialization, which for the past 20 years have been very massive.

This research is far from perfect. It is hoped that there will be many more researches that raise more in-depth and comprehensive information about bamboo cendani, the pride of Indonesia. Of course, there is great hope that the research results can be useful for the Indonesian people, especially the craftsmen of Joran cendani in particular to be able to increase their economic value. And for the world to add to the repertoire of scientists about bamboo cendani and more specifically the cendani bamboo rod.

"Long live Greater Indonesia"

\section{BIBLIOGRAPHY}

Apriliani A, Sukarsa, Hidayah HA (2014) KAJIAN ETNOBOTANI TUMBUHAN SEBAGAI BAHAN TAMBAHAN PANGAN SECARA TRADISIONAL OLEH MASYARAKAT DI KECAMATAN PEKUNCEN KABUPATEN BANYUMAS. Scr Biol 1:76-84. doi: 10.20884/1.sb.2014.1.1.30

Arsad E (2015) TEKNOLOGI PENGOLAHAN DAN MANFAAT BAMBU. J Ris Ind Has Hutan 7:45-52.

Artiningsih NKA (2012) Pemanfaatan bambu pada konstruksi bangunan berdampak positif bagi lingkungan. Metana 8:1-9. doi: 10.14710/metana.v8i01.5117

Badan Pusat Statistik. 2009. Kota Tidore Kepulauan dalam Angka. Tidore: Badan Pusat Statistik Kota Tidore Kepulauan

Baguna Lestari Firlawanti, Nurrochmat Ridho Dodik YYE (2015) POTENSI PENGEMBANGAN BAMBU TUTUL SEBAGAI KOMODITAS UNGGULAN DI MALUKU UTARA. Risal Kebijak Pertan DAN Lingkung Rumusan Kaji Strateg Bid Pertan dan Lingkung 2:42- 50. doi: 10.20957/jkebijakan.v2i1.10390

Batubara R (2002) Pemanfaatan Bambu di Indonesia. USU Digit Libr 1-7. doi: 14 Pbruari 2017

Batubara, R. (2002a) Morfologi Tanaman Bambu. Universitas Sumatra Utara.

(2002b) Pemanfaatan Bambu di Indonesia. Sumatera Utara. Diakses pada tanggal 21 maret 2017.

Bungin, B. (2007) Penelitian Kualitatif. Prenada Media Group: Jakarta.

Dewi, I.N. (2010) Potensi Konflik pada Pembangunan Taman Nasional BantimurungBulusaraung. Prosiding Balai Penelitian Kehutanan Saintifik@. Vol 1 (2) 
Oktober 2017 ISSN (e). 2598-3822 68 Makassar. Pusat Penelitian dan Pengembangan Konservasi dan Rehabilitasi. Bogor.

Duryatmo. 2000. Tanaman Bambu. Universitas Sumatra Utara.

Endang Naryono. (2020). Analisis Joran Bambu Cendani Terhadap Loyalitas Pemancing di Kota Sukabumi. Jurnal Ekonomedia STIE PASIM Vol.10. No.1. Sukabumi : P3M STIE PASIM

Endang Naryono. (2020). Strategi Pemasaran. Sukabumi : P3M STIE PASIM

Endang Naryono (2019). Pedoman Penulisan Skripsi Program Sarjana. Sukabumi ; P3M STIE PASIM

Fauzi Febrianto, Adiyantara Gumilang, Sena Maulana, et al (2014) Keawetan alami lima jenis bambu terhadap serangan rayap dan bubuk kayu kering. J Imu dan Teknol Kayu Trop 12:146-156.

Geertz, C. (1992) Kebudayaan dan Agama. Kanisius Press Yogyakarta.

Gustaf, Toto (2013) Aturan Adat untuk Jaga Kekayaan Sumberdaya Alam

Handayani, dan E. Gunaisah (2011) Kajian Perempuan Pesisir dalam Mendukung Konservasi Sumber Daya Pesisir di Kabupaten Raja Ampat. Jurnal Akuatika. Vol 2(1).

Julie (2005) Do Glaciers Listen : Local Knowledge, Colonial Encounters, and Social Imagination. Seattle: University of Washington Press.

Mayasari, A., dan Ady Suryawan (2012) Keragaman Jenis Bambu dan Pemanfaatannya di Taman Nasional Alas Purwo. Info BPK Manado. Vol 2(2).

Manuhuwa, E. (2009) Hasil Hutan Bukan Kayu Sebagai Bagian dari Pembangunan Hutan di Maluku. Pidato Pengukuhan Jabatan Guru Besar Tetap Dalam Jurusan Kehutanan Fakultas Pertanian Universitas Pattimura. Ambon.

Mulyadi, M. (2010) Pemberdayaan Masyarakat Adat dalam Pembangunan Kehutanan (Studi Kasus Komunitas Battang di Kota Palopo, Sulawesi).

Munziri, Riza L., dan Mukarlina (2013) Studi Etnobotani Bambu Oleh Masyarakat Dayak Kanayatan di Desa Saham Kecamatan Sengah Temila Kabupaten Landak. Protobiont Jurnal Ilmiah Biologi. Vol 2 (3) p: 112 - 116

Nazarea, V. (1999) Ethnoecology: Situated Knowledge/Located Lives. Tucson: The University of Arizona Press.

Ristianasari, P. Muljono, dan D.S. Gani (2013) Dampak Program Pemberdayaan Model Desa Konservasi terhadap Kemandirian Masyarakat: Kasus di Taman Nasional Bukit Barisan Selatan Lampung. e-Jurnal Penelitian Sosial dan Ekonomi Kehutanan. Vol 10 (3). ISSN(e).2502-4221

Sigit Prasetiyo (2010) Identifikasi Potensi dan Pemasaran Produk dari Hutan Rakyat Bambu Desa Pertumbukan Kabupaten Langkat. Sumatra Utara. Diakses pada tanggal 26 maret 2017. Spradley, J.P. (1997) Metode Etnografis. Yogyakarta : PT Tiara Wacana. 
Sukawi (2010) Bambu Sebagai Alternatif Bahan Bangunan. Jurnal TERAS Volume X Nomor 1, Juli 2010. Diakses pada tanggal 26 Maret 2016. Widjaja, E. A. (2001) Identifikasi Jenis-jenis Bambu di Kepulauan Sunda Kecil. 